\title{
Food and Consumer Attitude(s): An Overview of the Most Relevant Documents
}

\author{
Vítor João Pereira Domingues Martinho
}

check for updates

Citation: Martinho, V.J.P.D. Food and Consumer Attitude(s): An Overview of the Most Relevant Documents. Agriculture 2021, 11, 1183. https://doi.org/10.3390/ agriculture11121183

Academic Editor: Giuseppe Timpanaro

Received: 25 September 2021

Accepted: 21 November 2021

Published: 23 November 2021

Publisher's Note: MDPI stays neutral with regard to jurisdictional claims in published maps and institutional affiliations.

Copyright: (C) 2021 by the author. Licensee MDPI, Basel, Switzerland. This article is an open access article distributed under the terms and conditions of the Creative Commons Attribution (CC BY) license (https:/ / creativecommons.org/licenses/by/ $4.0 /)$.
CERNAS-IPV Research Centre, Polytechnic Institute of Viseu (IPV) and Agricultural School (ESAV), 3504-510 Viseu, Portugal; vdmartinho@esav.ipv.pt

\begin{abstract}
Food markets have, at least, two dimensions. One is related to supply, where food marketing, for example, plays a determinant role, namely to promote healthy and balanced consumption. The other dimension is associated with demand, where it is important to understand and bring insights about consumer attitudes, because they have implications on patterns of food consumption. In this framework, the main objective of this research is to suggest an alternative approach for conducting systematic reviews based on bibliometric analysis and implement it on topics about food and consumer attitudes. For this purpose, the most important bibliographic items (authors, sources, organizations, countries and documents) were identified and later the most relevant documents were reviewed. In addition, 908 documents were selected on 11 December 2020 from the Web of Science Core Collection, for the topics "food" and "consumer attitude", and analyzed through bibliometric analysis with the support of the VOSviewer and Gephi software. These documents were also benchmarked with those available in the Scopus scientific database. The approach presented here made it possible to highlight the main insights from the scientific literature related to consumer attitudes to food and bring about further contributions to a literature review supported by bibliometric analysis. This proposal may be known as MB2MBA2 (Methodology Based on Benchmarking of Metadata, from scientific databases, and Bibliometric Assessment and Analysis). This systematic review highlights that organic foods, food neophobia, climate change, marketing strategies and interrelationships between motivations-consumer attitudes-perceptions-purchase intentions-purchase decisions (MAPID) deserved special attention. In addition, MAPID interactions are impacted, among other dimensions, by labelling, branding and trust in the information provided. Future research should further address impacts on consumer attitudes towards food, such as those related to climate-smart agriculture, food 4.0, food security and protection, and climate change and malnutrition.
\end{abstract}

Keywords: bibliometric analysis; systematic literature review; VOSviewer; Gephi; bibliographic metrics

\section{Introduction}

The topic of food has several different dimensions, with not necessarily all of them being related to human consumption [1]. In any case, within the dimensions of the human lifestyle, food appears interrelated with many daily routine decisions and is interconnected with several special options. For example, every human being likes having a meal, but for foodies having meals at breakfast and dinner is a determinant factor for their well-being throughout the day and consequently for their choices [2]. In turn, jointly with water and energy, food is an important variable for a sustainable development [3].

The human relationship with food is influenced by its attitude as a consumer, after assessing for risks and benefits [4]. Here, the perception management by the several stakeholders is crucial, namely when it is intended to promote healthy attitudes. In turn, consumer perceptions about food are impacted by several factors, including consumer characteristics [5], food marketing [6], new technologies [7], the image of the food [8] and sensory attributes [9]. The consumer concerns regarding health have real implications in these relationships between perceptions and attitudes [10]. 
Consumer attitude is a complex phenomenon associated with multidimensional processes [11] where it is important to bring more insights about what happens upstream and downstream [12]. This phenomenon can be characterized as a feeling that a person has toward an object and is impacted by several factors, such as, for example, the brand logo [13]. Specifically, consumer attitude to food is, in fact, an important issue in human food consumption, namely in current times, where emerging concerns are for a sustainable development and healthy eating. A search in the Web of Science Core Collection [14] shows that there are no documents for the topics "food" and "consumer attitude" and "bibliometric" and only three studies were found on the Scopus database [15] (for a basic search considering article title, abstract and keywords). The documents found in the Scopus address ethical foods [16], food label design [17] and organic food in China [18]. This highlights that there is a huge gap here in literature which should be addressed.

Considering the context described before, the main objective of this research is to highlight the principal dimensions related with food and consumer attitudes through a systematic review based on an alternative/complementary approach taking into account bibliometric analysis. This approach was called as MB2MBA2 (Methodology Based on Benchmarking of Metadata, from scientific databases, and Bibliometric Assessment and Analysis).

\section{Materials and Methods}

A bibliometric analysis was firstly carried out to identify the most important (number of documents, citations and centrality metrics) items (authors, sources, organizations, countries and documents) associated with the documents found in the Web of Science Core Collection (WoS) for the topics "food" and "consumer attitude". Taking into account the large number of documents, information was presented only for the top 40 items (the 40 items with the most documents, citations or metrics). The WoS database was opted for after a benchmark with the Scopus platform. The topic "consumer attitude" was considered for a wider search, following, for example, Türkeli et al. [19]. In fact, the term "attitude* afforded the discovery of documents related to the words attitude and attitudes, for instance. This bibliometric analysis was supported by the VOSviewer $[20,21]$ and Gephi $[22$, 23] software. After this bibliometric analysis and considering the main insights from it, the most important documents were surveyed through literature review. In other words, the literature review is supported by the main outcomes from the bibliometric approach. Other studies have carried out a similar approach for the agricultural sector [24,25], food marketing [6], circular economy [26] and organizations management [27].

In summary, an approach within this study has been proposed which may be referred to as MB2MBA2 (Methodology Based on Benchmarking of Metadata, from scientific databases, and Bibliometric Assessment and Analysis), for a more structured and supported review, using the following steps [28]:

- Selection of the more adjusted scientific databases to work upon, considering the topics to be addressed;

- Collection of metadata information from the databases concerning the several dimensions;

- Benchmarking of the metadata information to analyze if the databases are alternative or complementary. The idea here is to verify if there are relevant differences that justify working with information from different databases;

- Assessment of the information obtained from the database(s) selected to identify better methods to be considered in the bibliometric analysis;

- Survey, through literature review, the most representative documents as a sample of the total results obtained in the search.

There are other approaches for systematic reviews, such as the PRISMA methodology [29]; however, the proposal presented here allows to deal more objectively with a high number of results for searches carried out in the scientific databases about certain topics. 


\section{Bibliometric Sample: Identification and Characterization}

For a search carried out on 11 December 2020 for the topics "food" and "consumer attitude*", 4996 documents were found on the WoS Core Collection [14] and Scopus [15] databases. The majority of these documents were obtained from the Scopus (4088) and fewer studies (908) were found on the Web of Science.

Figure 1, for the different number of documents presented by WoS and Scopus, highlights that there is a similar trend (to its scale) in the documents published over the last decades by these databases (with the Scopus having more documents in recent years), reaching a maximum in 2019. In fact, in 2020 it seems that there was a change in the focus of the researchers in some cases and a reduction in the total production of research in other contexts. In any case, these records were obtained on 11 December 2020 and this has influence in the number of documents obtained for 2020.

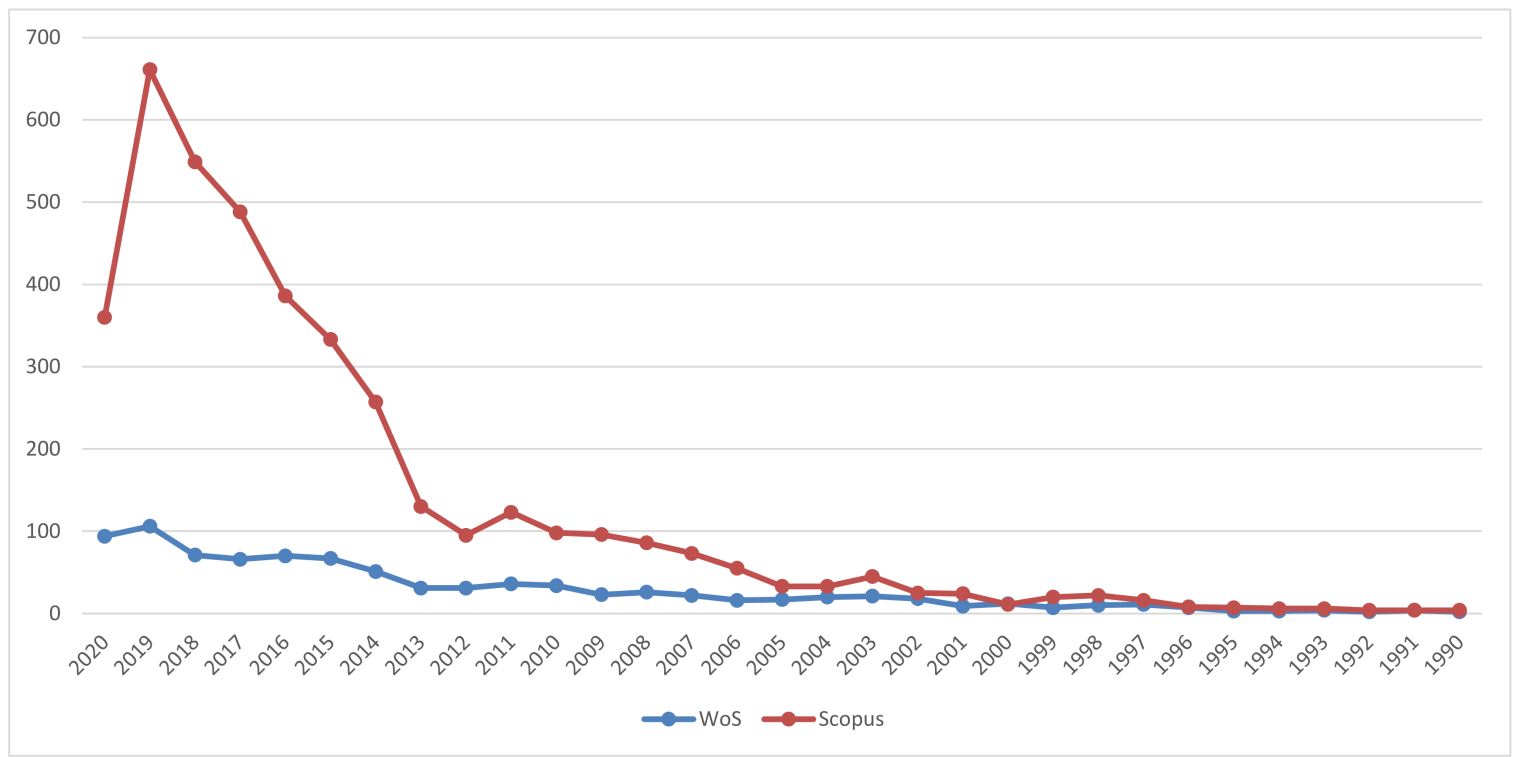

Figure 1. Evolution of the number of records (documents) over the last decades in the WoS and Scopus databases.

Table 1 also shows that there is some similitude between WoS and Scopus for the top 40 most productive sources (those having more records), indexed to these two databases, considered by the several researchers in publishing their studies. Note that in this table the sources marked in red are the top 40 that appear, for the topics considered in this research, simultaneously in WoS and in Scopus.

Table 1. Number of records for the top 40 most productive sources in the WoS and Scopus databases.

\begin{tabular}{|c|c|c|c|c|c|}
\hline \multicolumn{3}{|l|}{ WoS } & \multicolumn{3}{|l|}{ Scopus } \\
\hline Source & Number & $\%$ of 908 & Source & Number & $\%$ of 4088 \\
\hline British Food Journal & 90 & 10 & Appetite & 357 & 9 \\
\hline Food Quality and Preference & 52 & 6 & Meat Science & 212 & 5 \\
\hline Appetite & 34 & 4 & British Food Journal & 197 & 5 \\
\hline Sustainability & 22 & 2 & Journal Of Food Science & 169 & 4 \\
\hline Journal of Sensory Studies & 16 & 2 & Food Research International & 135 & 3 \\
\hline $\begin{array}{l}\text { Trends In Food Science } \\
\text { and Technology }\end{array}$ & 15 & 2 & Public Health Nutrition & 127 & 3 \\
\hline $\begin{array}{l}\text { International Journal of } \\
\text { Consumer Studies }\end{array}$ & 14 & 2 & Nutrients & 125 & 3 \\
\hline Journal of Cleaner Production & 13 & 1 & $\begin{array}{l}\text { Journal of the Science of Food } \\
\text { and Agriculture }\end{array}$ & 88 & 2 \\
\hline
\end{tabular}


Table 1. Cont.

\begin{tabular}{|c|c|c|c|c|c|}
\hline \multicolumn{3}{|l|}{ WoS } & \multicolumn{3}{|l|}{ Scopus } \\
\hline Source & Number & $\%$ of 908 & Source & Number & $\%$ of 4088 \\
\hline Meat Science & 13 & 1 & Plos One & 82 & 2 \\
\hline $\begin{array}{l}\text { Journal of Agricultural and } \\
\text { Environmental Ethics }\end{array}$ & 12 & 1 & $\begin{array}{l}\text { International Journal of Environmental } \\
\text { Research and Public Health }\end{array}$ & 81 & 2 \\
\hline Journal of Food Products Marketing & 11 & 1 & Food Quality and Preference & 60 & 1 \\
\hline Food Policy & 10 & 1 & Journal of Dairy Science & 47 & 1 \\
\hline Foods & 10 & 1 & BMC Public Health & 37 & 1 \\
\hline Journal of Food Science & 10 & 1 & Journal of Food Products Marketing & 37 & 1 \\
\hline Food Control & 8 & 1 & $\begin{array}{l}\text { International Journal of Behavioral } \\
\text { Nutrition and Physical Activity }\end{array}$ & 35 & 1 \\
\hline Nutrients & 8 & 1 & Food Chemistry & 32 & 1 \\
\hline Public Health Nutrition & 8 & 1 & $\begin{array}{l}\text { Journal of the Academy of Nutrition } \\
\text { and Dietetics }\end{array}$ & 31 & 1 \\
\hline Food Technology & 7 & 1 & $\begin{array}{c}\text { Critical Reviews in Food Science } \\
\text { and Nutrition }\end{array}$ & 28 & 1 \\
\hline $\begin{array}{l}\text { Innovative Food Science and } \\
\text { Emerging Technologies }\end{array}$ & 7 & 1 & $\begin{array}{l}\text { Food Science and Technology } \\
\text { International }\end{array}$ & 28 & 1 \\
\hline $\begin{array}{c}\text { International Journal of } \\
\text { Environmental Research and } \\
\text { Public Health }\end{array}$ & 7 & 1 & Sustainability & 26 & 1 \\
\hline European Journal of Clinical Nutrition & 6 & 1 & $\begin{array}{l}\text { Journal Of Nutrition Education } \\
\text { and Behavior }\end{array}$ & 23 & 1 \\
\hline Food Research International & 6 & 1 & $\begin{array}{l}\text { American Journal of } \\
\text { Preventive Medicine }\end{array}$ & 22 & 1 \\
\hline Journal of Food Safety & 6 & 1 & $\begin{array}{c}\text { Journal Of Food Agriculture } \\
\text { and Environment }\end{array}$ & 22 & 1 \\
\hline Plos One & 6 & 1 & American Journal of Clinical Nutrition & 21 & 1 \\
\hline Radiation Physics and Chemistry & 6 & 1 & European Journal of Clinical Nutrition & 20 & 0 \\
\hline Acta Horticulturae & 5 & 1 & $\begin{array}{c}\text { Journal of International Food and } \\
\text { Agribusiness Marketing }\end{array}$ & 20 & 0 \\
\hline American Journal of Clinical Nutrition & 5 & 1 & $\begin{array}{l}\text { International Journal of Consumer } \\
\text { Studies }\end{array}$ & 19 & 0 \\
\hline $\begin{array}{l}\text { International Journal of Food Science } \\
\text { and Technology }\end{array}$ & 5 & 1 & $\begin{array}{l}\text { International Journal of Food Sciences } \\
\text { and Nutrition }\end{array}$ & 19 & 0 \\
\hline Journal of Dairy Science & 5 & 1 & Journal Of Cleaner Production & 18 & 0 \\
\hline Journal of Economic Psychology & 5 & 1 & Trends in Food Science and Technology & 18 & 0 \\
\hline $\begin{array}{l}\text { Journal of Food Agriculture } \\
\text { and Environment }\end{array}$ & 5 & 1 & $\begin{array}{l}\text { Acta Scientiarum Polonorum } \\
\text { Technologia Alimentaria }\end{array}$ & 17 & 0 \\
\hline Journal of Islamic Marketing & 5 & 1 & $\begin{array}{l}\text { Journal Of Hunger and } \\
\text { Environmental Nutrition }\end{array}$ & 17 & 0 \\
\hline Acs Symposium Series & 4 & 0 & Waste Management & 17 & 0 \\
\hline Acta Alimentaria & 4 & 0 & British Journal of Nutrition & 16 & 0 \\
\hline $\begin{array}{l}\text { Agricultural Economics } \\
\text { Zemedelska Ekonomika }\end{array}$ & 4 & 0 & Journal of Food Protection & 16 & 0 \\
\hline $\begin{array}{c}\text { International Food and Agribusiness } \\
\text { Management Review }\end{array}$ & 4 & 0 & Food Control & 15 & 0 \\
\hline Journal of Agricultural Economics & 4 & 0 & Proceedings of the Nutrition Society & 15 & 0 \\
\hline $\begin{array}{l}\text { Journal Of Allergy and } \\
\text { Clinical Immunology }\end{array}$ & 4 & 0 & $\begin{array}{c}\text { International Food and Agribusiness } \\
\text { Management Review }\end{array}$ & 13 & 0 \\
\hline Journal of Food Protection & 4 & 0 & $\begin{array}{l}\text { International Journal of Food Science } \\
\text { and Technology }\end{array}$ & 13 & 0 \\
\hline Journal of Insects as Food and Feed & 4 & 0 & Food and Function & 12 & 0 \\
\hline
\end{tabular}

Note: The sources marked in red are the top 40 that appear, for the topics considered in this research, simultaneously in WoS and in Scopus.

For example, the sources "British Food Journal" and "Appetite" both received a relevant part of the studies indexed, regarding food and consumer attitudes, in both databases. British Food Journal has published 90 documents indexed to WoS and 197 studies in- 
dexed to Scopus. In turn, Appetite has had 34 records on the WoS and 357 documents on the Scopus.

British Food Journal, Food Quality and Preference, Appetite and Sustainability are the top four sources with more than 20 records on the WoS. Appetite, Meat Science, British Food Journal and Journal of Food Science are the sources with more than 150 records on the Scopus.

The analysis carried out before highlights that there is a similar trend (to its scale) in the studies published over the last decades on both WoS and Scopus. On the other hand, there is some coincidence in the top 40 most productive sources indexed to these two scientific databases. This framework reveals that, for different scales, the two databases may be an alternative for the topics worked on in this study. Considering these findings and the high number of records found on the Scopus, in the next section, for bibliometric analysis, only the records found on the WoS are considered.

\section{Bibliometric Analysis Considering Bibliographic Data}

In this section, to carry out the bibliometric analysis bibliographic data and the link bibliographic coupling are considered, where the relatedness of items is based on the number of references they share [20,21]. In fact, the link bibliographic coupling seems the more adjusted in order to identify the most relevant research to be surveyed through literature review. The link co-authorship could also be considered; however, the network is often weak and it is more difficult to obtain information for the item documents (in the VOSviewer, for example, the outputs available are for authors, organizations and countries).

\subsection{The Most Relevant and Networked Documents}

Table 2, obtained with the VOSviewer software, highlights that the most cited documents are Vermeir [30], Szczesniak [31] and Rico [32], including in terms of normalized citations. (Vermeir [30] is the document with higher normalized citations and Szczesniak [31] and Rico [32] are amongst the top 6. The normalized number of citations of research is the number of citations of the study weighted by the average number of citations of all documents published in the same year and included in the information that is delivered to the software. The normalization adjusts for the fact that older research may receive more citations than more recent studies [20]. Despite the higher number of citations and, in some cases, normalized citations, the documents presented in Table 2 are recent, the great majority from the last two decades.

Table 2. Bibliometric information for most cited documents (top 40).

\begin{tabular}{cccc}
\hline Document & Citations & Norm. Citations & Pub. Year \\
\hline Vermeir (2006) [30] & 877 & 10.88 & 2006 \\
Szczesniak (2002) [31] & 664 & 7.44 & 2002 \\
Rico (2007) [32] & 530 & 7.13 & 2007 \\
Vermeir (2008) [33] & 358 & 5.68 & 2008 \\
Roininen (1999) [34] & 352 & 5.04 & 1999 \\
Arvola (2008) [35] & 338 & 5.36 & 2008 \\
Yiridoe (2005) [36] & 323 & 5.17 & 2005 \\
Cook (1996) [37] & 316 & 3.79 & 1996 \\
Chen (2007) [38] & 290 & 3.90 & 2007 \\
Wilcock (2004) [39] & 245 & 5.45 & 2004 \\
Grunert (2002) [40] & 229 & 2.57 & 2002 \\
Siegrist (2008) [41] & 219 & 3.47 & 2008 \\
Onwezen (2013) [42] & 214 & 6.52 & 2013 \\
Maison (2004) [43] & 196 & 4.36 & 2004 \\
Lobb (2007) [44] & 194 & 2.61 & 2007 \\
\hline
\end{tabular}


Table 2. Cont.

\begin{tabular}{cccc}
\hline Document & Citations & Norm. Citations & Pub. Year \\
\hline Guerrero (2010) [45] & 188 & 4.67 & 2010 \\
Harker (2003) [46] & 186 & 4.23 & 2003 \\
Cook (2002) [47] & 184 & 2.06 & 2002 \\
Lusk (2004) [48] & 183 & 4.07 & 2004 \\
Lea (2005) [49] & 179 & 2.87 & 2005 \\
Saarela (2002) [50] & 156 & 1.75 & 2002 \\
Vanhonacker (2013) [51] & 152 & 4.63 & 2013 \\
Rana (2017) [52] & 151 & 10.75 & 2017 \\
Aertsens (2011) [53] & 151 & 5.22 & 2011 \\
Fernqvist (2014) [54] & 150 & 6.81 & 2014 \\
De Magistris (2008) [55] & 150 & 2.38 & 2008 \\
Hoek (2011) [56] & 146 & 5.04 & 2011 \\
Roininen (2001) [57] & 140 & 2.62 & 2001 \\
Ozsomer (2012) [58] & 139 & 6.85 & 2003 \\
Brown (2003) [59] & 139 & 3.16 & 2007 \\
Hefle (2007) [60] & 138 & 1.86 & 2003 \\
Bernues (2003) [61] & 136 & 3.09 & 2005 \\
Frewer (2005) [62] & 136 & 2.18 & 2001 \\
Burton (2001) [63] & 135 & 2.53 & 2007 \\
Buckley (2007) [64] & 134 & 1.80 & 1998 \\
Olson (1998) [65] & 129 & 2.91 & 2009 \\
Forbes (2009) [66] & 128 & 4.06 & 1998 \\
Lappalainen (1998) [67] & 128 & 2.89 & 2000 \\
Grunert (2000) [68] & 124 & 4.91 & 2010 \\
Lahteenmaki (2010) [69] & 122 & 3.03 &
\end{tabular}

In addition, results for the citations, normalized citations and publication year complemented by centrality metrics were analyzed. The centrality metrics were found through the Gephi $[22,23]$ software based on a file provided by the VOSviewer. These results show that there is a strong and positive correlation between the citations and the normalized citations in the items' documents, which highlights the fact that the year of publication has no great impact on the ranking found for the studies based on the number of citations. On the other hand, the correlation between the metrics obtained with the VOSviewer and those found through the Gephi are weak, with the exception for the publication year that has, for example, a relevant correlation with the closeness centrality (average distance between any two nodes in the network [70]). This reveals that the more recent documents have more relatedness (number of references they share).

In general, there are relevant correlations among the several centrality metrics presented following the respective meanings [22,23,70]: degree, number of edges associated with a node; eccentricity, distance from a node to the farthest node from it; closeness centrality, average distance between any two nodes in the network; betweenness centrality, quantifying how often a node appears on the shortest path between any two nodes; authority, estimates in the value of the content of the node; hub, estimates in the value given to other nodes; pageranks, probability of clicking through each node, given a number of casual clicks; clustering, measuring the connections between nodes; triangles, number of triangles that pass through each node; eigenvector centrality, measuring the node importance considering its connections to other nodes.

Nonetheless, the correlation seems to be stronger, for example, between the eigenvector centrality and the other centrality metrics. Considering this framework, the eigenvector centrality metric was taken into account to obtain the 40 most relevant documents, for the network, shown in Table A1. This table reveals that the documents with the publication scheduled for 2021 have higher eigenvector centrality, showing its relevance for the network and confirming the findings presented before that the most recent research has greater relatedness. 


\subsection{The Most Productive and Networked Sources}

Table A2 reveals that the most productive sources are the following: British Food Journal; Food Quality and Preference; Appetite; Sustainability; Journal of Sensory Studies; and Trends in Food Science and Technology. British Food Journal, Food Quality and Preference, Appetite, and Trends in Food Science and Technology are among the sources with more citations and normalized citations, showing again that the impacts from the publication year in these rankings are not strong. In turn, when the average citations are considered, the top sources are publications such as Ecological Economics (not presented in the table for the top 40 since it has only one document), showing the relevance of the number of documents for the total citation obtained by sources such as British Food Journal; Food Quality and Preference; Appetite; Sustainability; Journal of Sensory Studies; and Trends in Food Science and Technology.

In general, considering all the sources networked (not only the top 40), there are strong and positive correlations among the number of documents, total citations and normalized citations. In turn, there are weak correlations between the number of documents and the average citations. In addition, there are strong correlations between the total citations and normalized citations. This confirms the influence of the number of documents on the level of total and normalized citations and the weak impact from the publication year on the number of total citations.

\subsection{The Most Relevant and Networked Authors}

The most productive authors are those presented here (Table A3): Verbeke, Wim; Grunert, Klaus G.; Bruhn, Cm; Frewer, Lynn J.; Hamm, Ulrich; and Siegrist, Michael. Relative to the academic impact, Verbeke, Wim is the author who has been cited the most, in terms of total and normalized citations. However, in terms of average citations the author Vermeir, Iris (not presented in the table for the top 40) appears with higher impact. These results highlight the influence of the number of documents on the level of citations obtained by authors such as Verbeke, Wim.

When considering all the networked authors, the impact from the number of documents on the total and normalized citations is weaker than that found for the item sources, as well as the correlation between the total citations and the normalized citations, showing that here the publication year has more influence. This means that, in terms of total citations, the sources are more vulnerable to the number of documents and the authors are more vulnerable to the publication year.

\subsection{The Most Relevant and Networked Organizations}

Table A4 highlights that the organizations with more documents are the following: Univ Ghent; Univ Calif Davis; Newcastle Univ; Aarhus Univ; Wageningen Univ; Inra; Univ Gottingen; and Univ Guelph. The Univ Ghent is, also, the organization with more total citations and normalized citations.

A global analysis for the correlations between the several metrics presented on Table A4, for the organizations, reveals that the level of vulnerability of the total citations to the number of documents and the publication year is intermediate among the results found for the sources and authors. This shows, too, that the network found for the organizations is different from that obtained for the affiliated authors; however, the differences are not significantly relevant.

\subsection{The Most Productive and Networked Countries}

The most productive countries are the USA, England, Italy, Australia, Germany, Spain, China, Canada, Netherlands and Belgium (Figure 2). USA, Italy and England are, also, the countries with more citations. Belgium, for example, appears among the top countries with more total, normalized and average citations, showing its low vulnerability to the number of documents and publication year. 


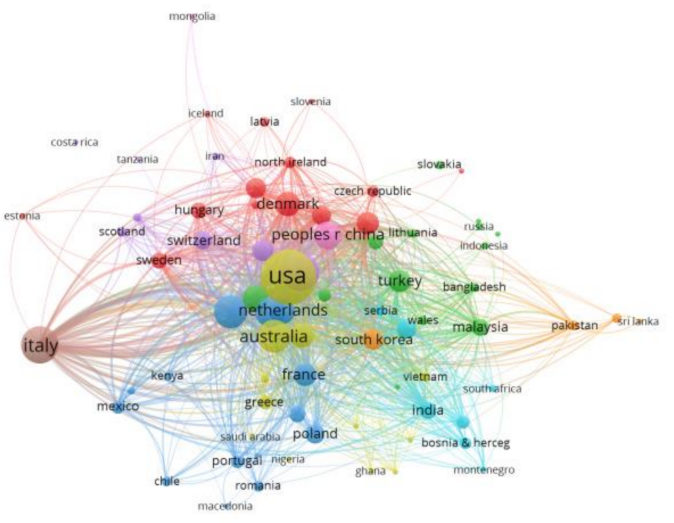

(a)

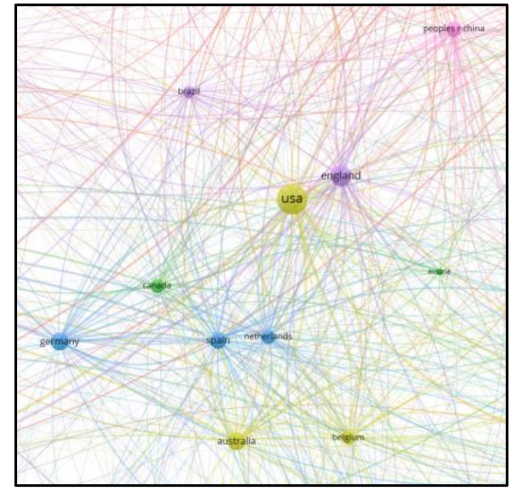

(b)

Figure 2. Network visualization map for the item countries (1 as the minimum number of documents of a country). (a) Original figure. (b) Enlargement of figure around the USA.

In general, there is, for this item, a stronger correlation, relative to the items analyzed before, between the number of documents and the total and normalized citations and between the total citations and the normalized citations. This means that the item country is the least influenced, in terms of total citations, by the publication year and the most impacted upon by the number of documents. This highlights, also, that the items documents, authors and organizations are more prone to become historic references and, in this way, be more cited over the years than the sources and the countries.

\section{Literature Review}

Taking into account the bibliometric analysis carried out before, in this section is assessed the top 40 most cited research and the top 40 most relevant studies considering centrality metrics.

\subsection{Insights from the Top 40 Most Cited Documents}

Food has several dimensions (gastronomic, environmental, social and economic), including a cultural one [37], and consumer attitudes related to the food are motivated by diverse variables. These relationships between consumer attitudes towards food consumption and the respective motivations are influenced by various factors, such as the brand [43], depending on the kind of market considered [58].

Consumer attitudes to organic agricultural products are favorable and positively influenced by knowledge about the organic food processes and respective markets [55]. This knowledge may be the result of the participation in environmental groups/organizations or having someone in the family who had contact with the agricultural sector [59]. The main motivations to consume this food are related to the absence of chemically processed 
crop protection products, quality, and environmental and health concerns. The health concerns are determinant factors for organic food consumption [52], which is seen as an investment in a healthy lifestyle [36]. Nonetheless, the consumers perceived these products as having higher prices than what they are willing to pay [66], and are sometimes not available in the markets [53]. The willingness to pay for organic food is not a unanimous finding among the researchers [51]. The consumer attitudes towards organic food also depend on the characteristics of each region, or country [35], on personality traits [38] and gender [49].

The labelling information has an impact on consumer attitudes concerning food consumption, namely through credence contents [54], related, in some cases, to health and quality domains [68]. The impact from food consumption on human health are great concerns for several stakeholders [50]. However, consumers do not always pay the expected attention to information present on labels [60] and claims about health have an impact on the perceptions of other attributes [69], in some cases negative ones. Age and gender influence consumer attitudes about health and taste characteristics of food [34] at both a national and supranational level [57]. Age and gender also impact the attitude to other sensory characteristics, such as texture [31]. Consumer trust in food labelling is crucial [62] for the design of their preferences. Indeed, their beliefs bring about interesting contributions to the interrelationships between motivations-consumer attitudes-perceptions-intentions to buy [46]. In any case, consumers tend to trust health professionals more [67]. The trust in food information supplied by the media (often negative), in turn, reduces the intention to purchase [44]. Intentions are influenced by attitudes, norms and behavioral control [42], as well as perceived food availability [30] and social influences [33]. Consumer attitudes may impact the perceptions about food and, consequently, the respective choices [40] and acceptance [56]. Consumer attitudes predict the behavior towards food consumption [39]. Perceptions about food are relevant domains influenced by several factors [45], where consumer attitudes are a part of this framework. The consume by date, the food's origin, nutritional characteristics, quality control and system of production are some of the labelling information content considered as being more relevant by consumers, namely that of meat [61].

Convenience food markets are other dimensions where it is important to analyze consumer attitudes, specifically to obtain insights which may be used as a support to the food industry [64]. Genetically modified organisms (GMOs) are another type of food product which have an influence on consumer attitudes [63]. In some circumstances, consumers are willing to pay to have food free of genetically modified organisms. The consumers that do not buy GMOs are those that consider these products as dangerous for the environment and health [47]. Consumer attitudes about biotechnology and the benefits for the environment, health and the third world all influence the acceptance of GMOs [48]. New food technologies were always a challenge for several stakeholders [65], but also open up several alternatives for the food industry [32]. Perceived risks, benefits and naturalness, as well as trust and food neophobia are dimensions that influence the acceptance of new food and technologies [41].

These top 40 most cited researchers focused on sustainable food, namely organic food, convenience food markets, genetically modified organisms and labelling information. A relevant part of the documents highlights the interrelationships between beliefs/motivationsconsumer attitudes-perceptions-intentions to buy and the respective dimensions that impact these interlinkages. Based on these findings, it may be important that future studies address even more deeply the interrelationships between consumer attitudes towards food and approaches associated with climate-smart agriculture, food 4.0, food security and safety and climate change.

\subsection{Contributions to Literature from the Top 40 Most Relevant Studies}

Such as was found for the most cited documents, also between the most relevant studies (considering centrality metrics), the organic food topic has its importance [53]. 
For the organic markets, knowledge [71], trust [72], pesticide concerns [73], willingness to pay [74] and subjective norms [75] and interrelationships with the consumer attitudes toward organic food are highlighted by these documents with better centrality metrics. In addition, food safety concerns [76], prices and availability are considered as barriers for a more sustainable food consumption [77] and the skepticism about health claims [78] are reinforced. The level of education has its influence on knowledge concerning organic foods [79]. Health and taste attitudes as predictors of food consumption [80], the dichotomy among local and global brands [81] and trust in information sources [82] are, again, strengthened.

The same happens with the interrelationships between the motivations-consumer attitudes-intentions to buy that appear highlighted by the top 40 most relevant documents [83], including for organic food [38] decisions [55], as well as for the labelling information, namely that related to health, environmental dimensions [84], animal welfare [85] and credence information [54]. The attitudes and intentions to have a personalized nutrition are associated with motives related to the price (negatively), health and ethical dimensions (positively). This is within the context of the European Union [86].

The fields related with food neophobia [87] and new technologies were also addressed [88], but now, in some studies, for more recent tendencies such as nanotechnologies [89], or new approaches such as those related to cultured meat [90]. In these frameworks related with new technologies and food neophobia, the socio-demographic characteristics have their implications on the intention to buy [91]. Nonetheless, in the organic food markets the altruistic motives are, for certain, circumstances which are perceived as being more important than the socio-demographic variables [92]. In any case, the social-demographic dimensions have their impacts on the organic food markets [93]. Neophobic/neophilic forces are, in certain contexts, the perceived risks, novelty, media impact, health and concerns about the environment [94].

However, these most relevant documents are in a significant part, more recent, and therefore bring about new insights. For example, for organic food consumption the relevance of psychological benefits were shown, such as a warm glow (involving socially recognized common good behavior) and self-expressive (showing self-identities to others), in the consumer attitudes and intentions to purchase [95]. Ethical values [96], tolerance of ambiguity [97] and financial barriers [98] were, also, presented as determinants of a sustainable food consumption. The purchasing decision appears as a final step after the purchase intention in Chinese organic food markets [99]. The traditional theory, such as the theory of planned behavior, was, similarly, extended for other markets (beyond the organic markets) with, for example, hedonic and utilitarian values [100] and putting together anticipated regret and risk perception [101].

There are new topics addressed by these most relevant studies, such as climate change and global warming, or the possibilities associated with insect foods [102]. Other topics which were emphasized are the specificities of the food markets [103] and the importance of the research findings for food marketing strategies [104] and the increase in demand of sustainable food [105]. Concerning food marketing, namely for new products, the role of the store frontline employees is emphasized [106].

The top 40 most relevant documents reinforced the importance of the topics related to organic food, interrelationships between motivations-consumer attitudes-intentions to purchase and food neophobia, already highlighted in the top 40 most cited research. However, these documents having better metrics, due to the fact that a relevant part of the studies is more recent, brought new approaches and new insights about food and consumer attitudes, namely associated with psychological benefits, ethical values, tolerance of ambiguity, financial constraints, hedonic and utilitarian values, and anticipated regret. They also brought up new topics such as those related to climate change and adjusted strategies for the markets and their respective marketing. In any case, future studies should go deeper into how consumers' attitudes towards food are perceived by producers, 
especially the smallest ones, and how they address these perceptions in decisions taken, including with regard to marketing.

\section{Discussion and Conclusions}

The main purpose of this research was to carry out a systematic review based on bibliometric analysis concerning the topics "food" and "consumer attitude*". For this purpose, an approach designed by MB2MBA2 (Methodology Based on Benchmarking of Metadata, from scientific databases, and Bibliometric Assessment and Analysis) was proposed. From a search performed on 11 December 2020 in the WoS Core Collection, 908 documents were considered. These studies were benchmarked with others found on the Scopus database for the same topics.

The benchmarking made between the WoS and Scopus databases for the topics addressed revealed that there is a great difference in the number of documents found (908 and 4088, respectively). Nonetheless, there is a high similitude among the metadata found on the two scientific platforms. In fact, a similar trend in the number of records over the last decades was observed along with some equivalence between the top 40 most productive sources, highlighting the importance for these topics, from sources such as British Food Journal and Appetite. These findings show that the two databases (WoS and Scopus) may be considered, in general terms, as alternatives. This analysis is useful, considering the total number of documents found.

The bibliometric analysis carried out with the support of the VOSviewer and Gephi (for centrality metrics) software highlighted the most relevant and networked documents, sources, authors, organizations and countries for the links bibliographic coupling (found as the most adjusted links to perform a systematic review). The documents from Vermeir [30], Szczesniak [31] and Rico [32] are the most cited, including when the potential impact from the number of years on the citations of the document is controlled. In turn, in terms of centrality metrics, the documents with greater importance inside the network are the following: Khalid [103]; Boobalan [95]; Nijssen [106].

The systematic literature review performed for the top 40 most cited and top 40 most relevant documents for the network show that the subtopics related to organic food, food neophobia, climate change, marketing strategies and interrelationships between motivations-consumer attitudes-perceptions-intentions to buy-decisions to purchase (MAPID) were the main subjects of study considered by the researchers for the topics "food" and "consumer attitude*". The scientific literature reveals, also, that the MAPID interactions are impacted by labelling, brand, trust on the information provided, knowledge, health and environmental concerns, socio-demographic variables, prices, food availability, food neophobia, credence information, ethical values, psychological benefits, tolerance of ambiguity, hedonic and utilitarian values and anticipated regret.

The research carried out in this study brings about new insights into the topic addressed that may be considered by the several stakeholders in the food sector, namely policymakers, farmers, manufactures, retailers and marketers. In addition, it highlights gaps, new directions for future research and proposes a systematic approach to deal with the high number of documents found on the scientific databases for several topic searches. For future research, more focus on public policies is suggested for a more sustainable food consumption.

Funding: This work is funded by National Funds through the FCT_-Foundation for Science and Technology, I.P., within the scope of the project $\operatorname{Ref}^{a}$ UIDB/00681/2020.

Institutional Review Board Statement: Not applicable.

Informed Consent Statement: Not applicable.

Data Availability Statement: Data will be available upon reasonable request to the corresponding author. 
Acknowledgments: Furthermore, we would like to thank the CERNAS Research Centre and the Polytechnic Institute of Viseu for their support.

Conflicts of Interest: The author declares no conflict of interest.

\section{Appendix A}

Table A1. The most relevant documents (top 40) considering centrality metrics.

\begin{tabular}{|c|c|}
\hline Documents & Eigenvector Centrality \\
\hline Khalid (2021) [103] & 1.00 \\
\hline Boobalan (2021) [95] & 0.95 \\
\hline Nijssen (2021) [106] & 0.84 \\
\hline Li (2020) [99] & 0.77 \\
\hline Hansmann (2020) [98] & 0.74 \\
\hline Teng (2015) [72] & 0.69 \\
\hline Chen (2007) [38] & 0.68 \\
\hline Grubor (2015) [80] & 0.67 \\
\hline Gassler (2018) [77] & 0.66 \\
\hline Ahmad (2019) [83] & 0.65 \\
\hline Chen (2008) [88] & 0.65 \\
\hline Vega-Zamora (2018) [105] & 0.64 \\
\hline Chang (2017) [89] & 0.63 \\
\hline Yazar (2019) [93] & 0.63 \\
\hline Grubor (2015) [81] & 0.62 \\
\hline Bravo (2013) [92] & 0.61 \\
\hline Dowd (2013) [96] & 0.60 \\
\hline Singh (2017) [75] & 0.60 \\
\hline Chang (2019) [102] & 0.59 \\
\hline Verneau (2014) [94] & 0.58 \\
\hline Jorge (2020) [97] & 0.58 \\
\hline Hsu (2016) [76] & 0.58 \\
\hline Nystrand (2020) [100] & 0.58 \\
\hline Aitken (2020) [84] & 0.57 \\
\hline Liang (2020) [104] & 0.57 \\
\hline Yarimoglu (2019) [101] & 0.56 \\
\hline Aertsens (2011) [53] & 0.56 \\
\hline Rankin (2018) [86] & 0.55 \\
\hline Coppola (2014) [91] & 0.55 \\
\hline Dentoni (2014) [85] & 0.55 \\
\hline De Magistris (2008) [55] & 0.55 \\
\hline Fernqvist (2014) [54] & 0.55 \\
\hline Lopez-Galan (2013) [79] & 0.55 \\
\hline Hoque (2018) [82] & 0.54 \\
\hline Kim (2020) [87] & 0.54 \\
\hline Cheung (2015) [71] & 0.54 \\
\hline Voon (2011) [74] & 0.54 \\
\hline Gineikiene (2017) [78] & 0.54 \\
\hline Tung (2012) [73] & 0.54 \\
\hline Zhang (2020) [90] & 0.54 \\
\hline
\end{tabular}


Table A2. Bibliometric information for the sources with more documents (top 40).

\begin{tabular}{|c|c|c|c|c|c|c|}
\hline Source & Documents & Citations & $\begin{array}{l}\text { Norm. } \\
\text { Citations }\end{array}$ & $\begin{array}{l}\text { Avg. Pub. } \\
\text { Year }\end{array}$ & $\begin{array}{l}\text { Avg. } \\
\text { Citations }\end{array}$ & $\begin{array}{l}\text { Avg. Norm. } \\
\text { Citations }\end{array}$ \\
\hline British Food Journal & 90 & 1681 & 77.45 & 2015.15 & 18.68 & 0.86 \\
\hline Food Quality and Preference & 52 & 2965 & 96.50 & 2011.58 & 57.02 & 1.86 \\
\hline Appetite & 34 & 2162 & 70.61 & 2011.82 & 63.59 & 2.08 \\
\hline Sustainability & 22 & 100 & 19.10 & 2018.73 & 4.55 & 0.87 \\
\hline Journal of Sensory Studies & 16 & 182 & 6.16 & 2011.53 & 11.38 & 0.38 \\
\hline $\begin{array}{l}\text { Trends in Food Science } \\
\text { and Technology }\end{array}$ & 15 & 1548 & 35.57 & 2010.87 & 103.20 & 2.37 \\
\hline $\begin{array}{c}\text { International Journal of Consumer } \\
\text { Studies }\end{array}$ & 14 & 167 & 7.17 & 2012.85 & 11.93 & 0.51 \\
\hline Journal of Cleaner Production & 13 & 330 & 30.97 & 2017.92 & 25.38 & 2.38 \\
\hline Meat Science & 13 & 513 & 25.57 & 2012.92 & 39.46 & 1.97 \\
\hline $\begin{array}{l}\text { Journal of Agricultural and } \\
\text { Environmental Ethics }\end{array}$ & 12 & 1339 & 30.91 & 2013.33 & 111.58 & 2.58 \\
\hline $\begin{array}{l}\text { Journal of Food } \\
\text { Products Marketing }\end{array}$ & 11 & 82 & 9.82 & 2017.70 & 7.45 & 0.89 \\
\hline Food Policy & 10 & 401 & 11.37 & 2009.80 & 40.10 & 1.14 \\
\hline Foods & 10 & 57 & 9.99 & 2019.10 & 5.70 & 1.00 \\
\hline Journal of Food Science & 10 & 318 & 9.30 & 2005.60 & 31.80 & 0.93 \\
\hline Food Control & 8 & 100 & 6.76 & 2015.88 & 12.50 & 0.84 \\
\hline Nutrients & 8 & 20 & 4.56 & 2018.88 & 2.50 & 0.57 \\
\hline Public Health Nutrition & 8 & 166 & 8.25 & 2010.63 & 20.75 & 1.03 \\
\hline Food Technology & 7 & 266 & 8.47 & 1996.00 & 38.00 & 1.21 \\
\hline $\begin{array}{l}\text { Innovative Food Science and } \\
\text { Emerging Technologies } \\
\text { International Journal of }\end{array}$ & 7 & 284 & 12.98 & 2011.71 & 40.57 & 1.85 \\
\hline $\begin{array}{l}\text { Environmental Research and } \\
\text { Public Health }\end{array}$ & 7 & 56 & 12.01 & 2018.71 & 8.00 & 1.72 \\
\hline $\begin{array}{c}\text { European Journal of } \\
\text { Clinical Nutrition }\end{array}$ & 6 & 174 & 5.79 & 1999.83 & 29.00 & 0.97 \\
\hline Food Research International & 6 & 133 & 6.73 & 2014.67 & 22.17 & 1.12 \\
\hline Journal of Food Safety & 6 & 226 & 4.67 & 2002.67 & 37.67 & 0.78 \\
\hline Plos One & 6 & 79 & 4.98 & 2017.33 & 13.17 & 0.83 \\
\hline Radiation Physics and Chemistry & 6 & 87 & 3.52 & 1999.50 & 14.50 & 0.59 \\
\hline $\begin{array}{c}\text { American Journal of } \\
\text { Clinical Nutrition }\end{array}$ & 5 & 65 & 2.84 & 2002.80 & 13.00 & 0.57 \\
\hline $\begin{array}{l}\text { International Journal of Food } \\
\text { Science and Technology }\end{array}$ & 5 & 94 & 5.71 & 2009.20 & 18.80 & 1.14 \\
\hline Journal of Dairy Science & 5 & 76 & 3.32 & 2008.40 & 15.20 & 0.66 \\
\hline Journal of Economic Psychology & 5 & 455 & 13.02 & 2012.60 & 91.00 & 2.60 \\
\hline $\begin{array}{c}\text { Journal of Food Agriculture and } \\
\text { Environment }\end{array}$ & 5 & 63 & 1.71 & 2008.80 & 12.60 & 0.34 \\
\hline Journal of Islamic Marketing & 5 & 19 & 1.87 & 2017.50 & 3.80 & 0.37 \\
\hline Acta Alimentaria & 4 & 8 & 0.29 & 2013.00 & 2.00 & 0.07 \\
\hline $\begin{array}{l}\text { Agricultural Economics } \\
\text { Zemedelska Ekonomika } \\
\text { International Food and }\end{array}$ & 4 & 48 & 2.31 & 2012.75 & 12.00 & 0.58 \\
\hline $\begin{array}{c}\text { Agribusiness Management } \\
\text { Review }\end{array}$ & 4 & 121 & 4.63 & 2012.50 & 30.25 & 1.16 \\
\hline Journal of Agricultural Economics & 4 & 97 & 2.84 & 2008.00 & 24.25 & 0.71 \\
\hline $\begin{array}{l}\text { Journal of Allergy and Clinical } \\
\text { Immunology }\end{array}$ & 4 & 216 & 4.38 & 2010.00 & 54.00 & 1.09 \\
\hline Journal of Food Protection & 4 & 195 & 5.08 & 2004.75 & 48.75 & 1.27 \\
\hline $\begin{array}{l}\text { Journal of Insects as Food } \\
\text { and Feed }\end{array}$ & 4 & 21 & 11.23 & 2019.75 & 5.25 & 2.81 \\
\hline $\begin{array}{l}\text { Journal of Retailing and } \\
\text { Consumer Services }\end{array}$ & 4 & 234 & 17.11 & 2018.00 & 58.50 & 4.28 \\
\hline Journal of Risk Research & 4 & 65 & 2.82 & 2012.25 & 16.25 & 0.70 \\
\hline
\end{tabular}


Table A3. Bibliometric information for the authors with more documents (top 40).

\begin{tabular}{|c|c|c|c|c|c|c|}
\hline Authors & Documents & Citations & $\begin{array}{l}\text { Norm. } \\
\text { Citations }\end{array}$ & $\begin{array}{l}\text { Avg. Pub. } \\
\text { Year }\end{array}$ & $\begin{array}{c}\text { Avg. } \\
\text { Citations }\end{array}$ & $\begin{array}{l}\text { Avg. Norm. } \\
\text { Citations }\end{array}$ \\
\hline Verbeke, Wim & 18 & 2110 & 47.29 & 2011.61 & 117.22 & 2.63 \\
\hline Grunert, Klaus G. & 8 & 168 & 12.17 & 2014.25 & 21.00 & 1.52 \\
\hline Bruhn, CM & 7 & 223 & 7.21 & 1994.43 & 31.86 & 1.03 \\
\hline Frewer, Lynn J. & 7 & 183 & 13.28 & 2014.57 & 26.14 & 1.90 \\
\hline Hamm, Ulrich & 7 & 175 & 7.02 & 2013.14 & 25.00 & 1.00 \\
\hline Siegrist, Michael & 7 & 353 & 10.03 & 2013.71 & 50.43 & 1.43 \\
\hline Clark, Beth & 6 & 103 & 11.43 & 2018.67 & 17.17 & 1.91 \\
\hline Fischer, Arnout R. H. & 6 & 79 & 9.27 & 2016.50 & 13.17 & 1.55 \\
\hline Frewer, LJ & 5 & 400 & 7.71 & 2000.20 & 80.00 & 1.54 \\
\hline Lahteenmaki, L & 5 & 776 & 11.51 & 2001.40 & 155.20 & 2.30 \\
\hline Shepherd, R & 5 & 237 & 7.12 & 1994.60 & 47.40 & 1.42 \\
\hline Spiller, Achim & 5 & 154 & 6.56 & 2015.40 & 30.80 & 1.31 \\
\hline Vanhonacker, Filiep & 5 & 523 & 15.76 & 2011.60 & 104.60 & 3.15 \\
\hline Ares, Gaston & 4 & 177 & 4.11 & 2009.00 & 44.25 & 1.03 \\
\hline Dean, Moira & 4 & 120 & 5.34 & 2014.00 & 30.00 & 1.34 \\
\hline Gaviglio, Anna & 4 & 26 & 2.11 & 2015.00 & 6.50 & 0.53 \\
\hline Grunert, KG & 4 & 504 & 10.20 & 2002.00 & 126.00 & 2.55 \\
\hline Lahteenmaki, Liisa & 4 & 245 & 6.75 & 2008.75 & 61.25 & 1.69 \\
\hline Scarpato, Debora & 4 & 32 & 1.71 & 2016.00 & 8.00 & 0.43 \\
\hline Simeone, Mariarosaria & 4 & 19 & 1.41 & 2016.75 & 4.75 & 0.35 \\
\hline Weinrich, Ramona & 4 & 43 & 3.27 & 2017.75 & 10.75 & 0.82 \\
\hline Aleksejeva, Inese & 3 & 15 & 0.68 & 2015.67 & 5.00 & 0.23 \\
\hline Annunziata, Azzurra & 3 & 52 & 1.88 & 2012.33 & 17.33 & 0.63 \\
\hline Aschemann-Witzel, Jessica & 3 & 21 & 3.78 & 2018.00 & 7.00 & 1.26 \\
\hline Banati, Diana & 3 & 100 & 4.07 & 2012.00 & 33.33 & 1.36 \\
\hline Banterle, Alessandro & 3 & 8 & 1.01 & 2017.00 & 2.67 & 0.34 \\
\hline Behrens, Jorge H. & 3 & 63 & 1.93 & 2010.33 & 21.00 & 0.64 \\
\hline Bruhn, Christine $\mathrm{M}$. & 3 & 97 & 3.54 & 2010.33 & 32.33 & 1.18 \\
\hline Connor, Melanie & 3 & 89 & 2.78 & 2013.00 & 29.67 & 0.93 \\
\hline D'amico, Mario & 3 & 17 & 3.96 & 2018.00 & 5.67 & 1.32 \\
\hline De Barcellos, Marcia Dutra & 3 & 110 & 6.16 & 2013.33 & 36.67 & 2.05 \\
\hline Dean, $\mathrm{M}$ & 3 & 422 & 9.34 & 2011.33 & 140.67 & 3.11 \\
\hline Demartini, Eugenio & 3 & 23 & 1.92 & 2015.00 & 7.67 & 0.64 \\
\hline Di Vita, Giuseppe & 3 & 18 & 4.49 & 2019.33 & 6.00 & 1.50 \\
\hline Egan, Bernadette & 3 & 49 & 2.92 & 2015.67 & 16.33 & 0.97 \\
\hline Filimonau, Viachaslau & 3 & 7 & 3.39 & 2019.33 & 2.33 & 1.13 \\
\hline Fraser, Iain & 3 & 50 & 1.77 & 2012.50 & 16.67 & 0.59 \\
\hline Frewer, Lynn & 3 & 16 & 2.53 & 2017.67 & 5.33 & 0.84 \\
\hline Gil, Jose M. & 3 & 44 & 2.10 & 2012.67 & 14.67 & 0.70 \\
\hline Gimenez, Ana & 3 & 132 & 2.99 & 2008.67 & 44.00 & 1.00 \\
\hline
\end{tabular}

Table A4. Bibliometric information for the organizations which have more documents (top 40).

\begin{tabular}{lllllll}
\hline Organizations & Documents & Citations & $\begin{array}{l}\text { Norm. } \\
\text { Citations }\end{array}$ & $\begin{array}{l}\text { Avg. Pub. } \\
\text { Year }\end{array}$ & $\begin{array}{l}\text { Avg. } \\
\text { Citations }\end{array}$ & $\begin{array}{l}\text { Avg. Norm. } \\
\text { Citations }\end{array}$ \\
\hline Univ Ghent & 28 & 2262 & 55.20 & 2012.67 & 80.79 & 1.97 \\
Univ Calif Davis & 16 & 293 & 10.90 & 2001.19 & 18.31 & 0.68 \\
Newcastle Univ & 15 & 196 & 19.33 & 2017.00 & 13.07 & 1.29 \\
Aarhus Univ & 14 & 334 & 23.17 & 2015.31 & 23.86 & 1.66 \\
Wageningen Univ & 13 & 626 & 32.19 & 2015.15 & 48.15 & 2.48 \\
INRA & 12 & 454 & 14.89 & 2010.58 & 37.83 & 1.24 \\
Univ Gottingen & 12 & 283 & 12.59 & 2015.00 & 23.58 & 1.05 \\
Univ Guelph & 12 & 352 & 10.00 & 2013.17 & 29.33 & 0.83 \\
Univ Adelaide & 9 & 69 & 10.68 & 2017.78 & 7.67 & 1.19 \\
Univ Arkansas & 8 & 172 & 7.96 & 2014.38 & 21.50 & 1.00 \\
Univ Kassel & 8 & 176 & 7.56 & 2014.00 & 22.00 & 0.94 \\
\hline
\end{tabular}


Table A4. Cont.

\begin{tabular}{|c|c|c|c|c|c|c|}
\hline Organizations & Documents & Citations & $\begin{array}{l}\text { Norm. } \\
\text { Citations }\end{array}$ & $\begin{array}{l}\text { Avg. Pub. } \\
\text { Year }\end{array}$ & $\begin{array}{l}\text { Avg. } \\
\text { Citations }\end{array}$ & $\begin{array}{l}\text { Avg. Norm. } \\
\text { Citations }\end{array}$ \\
\hline Univ Reading & 8 & 418 & 11.62 & 2014.86 & 52.25 & 1.45 \\
\hline Univ Surrey & 8 & 544 & 12.74 & 2012.88 & 68.00 & 1.59 \\
\hline Queens Univ Belfast & 7 & 158 & 9.92 & 2015.14 & 22.57 & 1.42 \\
\hline Swedish Univ Agr Sci & 7 & 183 & 10.13 & 2015.43 & 26.14 & 1.45 \\
\hline Univ Florence & 7 & 126 & 13.45 & 2018.00 & 18.00 & 1.92 \\
\hline Univ Florida & 7 & 229 & 8.73 & 2012.43 & 32.71 & 1.25 \\
\hline Univ Milan & 7 & 79 & 5.81 & 2015.33 & 11.29 & 0.83 \\
\hline Univ Sao Paulo & 7 & 239 & 7.37 & 2010.14 & 34.14 & 1.05 \\
\hline Univ Wageningen \& Res Ctr & 7 & 474 & 13.42 & 2011.00 & 67.71 & 1.92 \\
\hline Purdue Univ & 6 & 223 & 8.11 & 2013.60 & 37.17 & 1.35 \\
\hline Univ Coll Dublin & 6 & 179 & 7.40 & 2011.17 & 29.83 & 1.23 \\
\hline Univ Copenhagen & 6 & 79 & 5.95 & 2015.67 & 13.17 & 0.99 \\
\hline Univ Illinois & 6 & 177 & 3.44 & 2007.50 & 29.50 & 0.57 \\
\hline Univ Naples Federico Ii & 6 & 154 & 13.85 & 2015.83 & 25.67 & 2.31 \\
\hline CSIC & 5 & 153 & 4.31 & 2010.00 & 30.60 & 0.86 \\
\hline Curtin Univ & 5 & 36 & 4.49 & 2017.60 & 7.20 & 0.90 \\
\hline Ewha Womans Univ & 5 & 20 & 0.89 & 2015.80 & 4.00 & 0.18 \\
\hline Iowa State Univ & 5 & 220 & 7.85 & 2009.20 & 44.00 & 1.57 \\
\hline Kansas State Univ & 5 & 113 & 3.65 & 2009.60 & 22.60 & 0.73 \\
\hline Swiss Fed Inst Technol & 5 & 18 & 4.49 & 2018.20 & 3.60 & 0.90 \\
\hline Univ Bologna & 5 & 508 & 12.37 & 2010.80 & 101.60 & 2.47 \\
\hline Univ Catania & 5 & 65 & 7.38 & 2017.20 & 13.00 & 1.48 \\
\hline Univ Kent & 5 & 81 & 3.07 & 2011.50 & 16.20 & 0.61 \\
\hline Univ Kiel & 5 & 166 & 7.63 & 2012.60 & 33.20 & 1.53 \\
\hline Univ Naples Parthenope & 5 & 41 & 1.91 & 2014.80 & 8.20 & 0.38 \\
\hline Univ Western Australia & 5 & 215 & 5.84 & 2011.20 & 43.00 & 1.17 \\
\hline Univ Wollongong & 5 & 92 & 4.01 & 2013.80 & 18.40 & 0.80 \\
\hline Univ Zaragoza & 5 & 148 & 5.23 & 2015.00 & 29.60 & 1.05 \\
\hline Vrije Univ Amsterdam & 5 & 224 & 8.56 & 2017.80 & 44.80 & 1.71 \\
\hline
\end{tabular}

\section{References}

1. Bagchi, S.; Mishra, C.; Bhatnagar, Y.V. Conflicts between traditional pastoralism and conservation of Himalayan ibex (Capra sibirica) in the Trans-Himalayan mountains. Anim. Conserv. 2004, 7, 121-128. [CrossRef]

2. Bjork, P.; Kauppinen-Raisanen, H. A destination's gastronomy as a means for holiday well-being. Br. Food J. 2017, 119, 1578-1591. [CrossRef]

3. Giupponi, C.; Gain, A.K. Integrated spatial assessment of the water, energy and food dimensions of the Sustainable Development Goals. Reg. Environ. Chang. 2017, 17, 1881-1893. [CrossRef]

4. Gupta, V.; Khanna, K.; Gupta, R.K. A study on the street food dimensions and its effects on consumer attitude and behavioural intentions. Tour. Rev. 2018, 73, 374-388. [CrossRef]

5. Kyutoku, Y.; Minami, Y.; Koizumi, T.; Okamoto, M.; Kusakabe, Y.; Dan, I. Conceptualization of food choice motives and consumption among Japanese in light of meal, gender, and age effects. Food Qual. Prefer. 2012, 24, 213-217. [CrossRef]

6. Martinho, V.J.P.D. Food Marketing as a Special Ingredient in Consumer Choices: The Main Insights from Existing Literature. Foods 2020, 9, 1651. [CrossRef]

7. Lam, M.C.; Suwadi, N.A.; Arifien, A.H.M.Z.; Poh, B.K.; Safii, N.S.; Wong, J.E. An evaluation of a virtual atlas of portion sizes (VAPS) mobile augmented reality for portion size estimation. Virtual Real. 2020, 25, 695-707. [CrossRef]

8. Padulo, C.; Carlucci, L.; Marzoli, D.; Manippa, V.; Tommasi, L.; Saggino, A.; Puglisi-Allegra, S.; Brancucci, A. Affective evaluation of food images according to stimulus and subject characteristics. J. Hum. Nutr. Diet. 2018, 31, 715-724. [CrossRef]

9. Tonacci, A.; di Monte, J.; Meucci, M.B.; Sansone, F.; Pala, A.P.; Billeci, L.; Conte, R. Wearable Sensors to Characterize the Autonomic Nervous System Correlates of Food-Like Odors Perception: A Pilot Study. Electronics 2019, 8, 1481. [CrossRef]

10. Thome, K.M.; Cappellesso, G.; Pinho, G.M. Food consumption values and the influence of physical activity. Br. Food J. 2021, 123, 943-957. [CrossRef]

11. Hsu, L.-C. Antecedents and consequences of attitude contagion processes: The example of apparel brand fan pages. J. Prod. Brand Manag. 2020, 29, 31-51. [CrossRef]

12. Amoroso, D.; Lim, R. The mediating effects of habit on continuance intention. Int. J. Inf. Manag. 2017, 37, 693-702. [CrossRef]

13. Septianto, F.; Paramita, W. Cute brand logo enhances favorable brand attitude: The moderating role of hope. J. Retail. Consum. Serv. 2021, 63, 102734. [CrossRef] 
14. Web of Science Core Collection. Available online: https://apps.webofknowledge.com/WOS_GeneralSearch_input.do?product= WOS\&search_mode=GeneralSearch\&SID=C3Untcj7br87QmyjDLK\&preferencesSaved= (accessed on 11 December 2020).

15. Scopus Scopus Database. Available online: https://www.scopus.com/search/form.uri?display=basic (accessed on 11 December 2020).

16. Della Corte, V.; del Gaudio, G.; Sepe, F. Ethical food and the kosher certification: A literature review. Br. Food J. 2018, 120, 2270-2288. [CrossRef]

17. Latino, M.E.; Menegoli, M.; Corallo, A. Food label design—exploring the literature. Br. Food J. 2019, 122, 766-778. [CrossRef]

18. Li, R.; Lee, H.-Y.; Lin, Y.-T.; Liu, C.-W.; Tsai, P.F. Consumers'willingness to pay for organic foods in China: Bibliometric review for an emerging literature. Int. J. Environ. Res. Public. Health 2019, 16, 1713. [CrossRef]

19. Türkeli, S.; Kemp, R.; Huang, B.; Bleischwitz, R.; McDowall, W. Circular economy scientific knowledge in the European Union and China: A bibliometric, network and survey analysis (2006-2016). J. Clean. Prod. 2018, 197, 1244-1261. [CrossRef]

20. Van Eck, N.J.; Waltman, L. VOSviewer Manual. Available online: https://www.vosviewer.com/documentation/Manual_ VOSviewer_1.6.16.pdf (accessed on 11 December 2020).

21. VOSviewer VOSviewer-Visualizing scientific landscapes. Available online: https:/ /www.vosviewer.com// (accessed on 11 December 2020).

22. Bastian, M.; Heymann, S.; Jacomy, M. Gephi: An Open Source Software for Exploring and Manipulating Networks. In Proceedings of the Third international AAAI Conference on Weblogs and Social Media, San Jose, CA, USA, 17-20 May 2009.

23. Gephi Gephi-The Open Graph Viz Platform. Available online: https://gephi.org/ (accessed on 11 December 2020).

24. Martinho, V.J.P.D. Interrelationships between renewable energy and agricultural economics: An overview. Energy Strategy Rev. 2018, 22, 396-409. [CrossRef]

25. Martinho, V.J.P.D. Best management practices from agricultural economics: Mitigating air, soil and water pollution. Sci. Total Environ. 2019, 688, 346-360. [CrossRef]

26. Martinho, V.D.; Mourão, P.R. Circular Economy and Economic Development in the European Union: A Review and Bibliometric Analysis. Sustainability 2020, 12, 7767. [CrossRef]

27. Kent Baker, H.; Pandey, N.; Kumar, S.; Haldar, A. A bibliometric analysis of board diversity: Current status, development, and future research directions. J. Bus. Res. 2020, 108, 232-246. [CrossRef]

28. Martinho, V.J.P.D. Agri-Food Contexts in Mediterranean Regions: Contributions to Better Resources Management. Sustainability 2021, 13, 6683. [CrossRef]

29. Liberati, A.; Altman, D.G.; Tetzlaff, J.; Mulrow, C.; Gøtzsche, P.C.; Ioannidis, J.P.A.; Clarke, M.; Devereaux, P.J.; Kleijnen, J.; Moher, D. The PRISMA Statement for Reporting Systematic Reviews and Meta-Analyses of Studies That Evaluate Health Care Interventions: Explanation and Elaboration. PLoS Med. 2009, 6, e1000100. [CrossRef]

30. Vermeir, I.; Verbeke, W. Sustainable Food Consumption: Exploring the Consumer "Attitude-Behavioral Intention" Gap. J. Agric. Environ. Ethics 2006, 19, 169-194. [CrossRef]

31. Szczesniak, A.S. Texture is a sensory property. Food Qual. Prefer. 2002, 13, 215-225. [CrossRef]

32. Rico, D.; Martín-Diana, A.B.; Barat, J.M.; Barry-Ryan, C. Extending and measuring the quality of fresh-cut fruit and vegetables: A review. Trends Food Sci. Technol. 2007, 18, 373-386. [CrossRef]

33. Vermeir, I.; Verbeke, W. Sustainable food consumption among young adults in Belgium: Theory of planned behaviour and the role of confidence and values. Ecol. Econ. 2008, 64, 542-553. [CrossRef]

34. Roininen, K.; Lähteenmäki, L.; Tuorila, H. Quantification of Consumer Attitudes to Health and Hedonic Characteristics of Foods. Appetite 1999, 33, 71-88. [CrossRef]

35. Arvola, A.; Vassallo, M.; Dean, M.; Lampila, P.; Saba, A.; Lähteenmäki, L.; Shepherd, R. Predicting intentions to purchase organic food: The role of affective and moral attitudes in the Theory of Planned Behaviour. Appetite 2008, 50, 443-454. [CrossRef]

36. Yiridoe, E.K.; Bonti-Ankomah, S.; Martin, R.C. Comparison of consumer perceptions and preference toward organic versus conventionally produced foods: A review and update of the literature. Renew. Agric. Food Syst. 2005, 20, 193-205. [CrossRef]

37. Cook, I.; Crang, P. The World On a Plate: Culinary Culture, Displacement and Geographical Knowledges. J. Mater. Cult. 1996, 1, 131-153. [CrossRef]

38. Chen, M.-F. Consumer attitudes and purchase intentions in relation to organic foods in Taiwan: Moderating effects of food-related personality traits. Food Qual. Prefer. 2007, 18, 1008-1021. [CrossRef]

39. Wilcock, A.; Pun, M.; Khanona, J.; Aung, M. Consumer attitudes, knowledge and behaviour: A review of food safety issues. Trends Food Sci. Technol. 2004, 15, 56-66. [CrossRef]

40. Grunert, K.G. Current issues in the understanding of consumer food choice. Trends Food Sci. Technol. 2002, 13, 275-285. [CrossRef]

41. Siegrist, M. Factors influencing public acceptance of innovative food technologies and products. Trends Food Sci. Technol. 2008, 19, 603-608. [CrossRef]

42. Onwezen, M.C.; Antonides, G.; Bartels, J. The Norm Activation Model: An exploration of the functions of anticipated pride and guilt in pro-environmental behaviour. J. Econ. Psychol. 2013, 39, 141-153. [CrossRef]

43. Maison, D.; Greenwald, A.G.; Bruin, R.H. Predictive Validity of the Implicit Association Test in Studies of Brands, Consumer Attitudes, and Behavior. J. Consum. Psychol. 2004, 14, 405-415. [CrossRef]

44. Lobb, A.E.; Mazzocchi, M.; Traill, W.B. Modelling risk perception and trust in food safety information within the theory of planned behaviour. Food Qual. Prefer. 2007, 18, 384-395. [CrossRef] 
45. Guerrero, L.; Claret, A.; Verbeke, W.; Enderli, G.; Zakowska-Biemans, S.; Vanhonacker, F.; Issanchou, S.; Sajdakowska, M.; Granli, B.S.; Scalvedi, L.; et al. Perception of traditional food products in six European regions using free word association. Food Qual. Prefer. 2010, 21, 225-233. [CrossRef]

46. Harker, F.R.; Gunson, F.A.; Jaeger, S.R. The case for fruit quality: An interpretive review of consumer attitudes, and preferences for apples. Postharvest Biol. Technol. 2003, 28, 333-347. [CrossRef]

47. Cook, A.J.; Kerr, G.N.; Moore, K. Attitudes and intentions towards purchasing GM food. J. Econ. Psychol. 2002, 23, 557-572. [CrossRef]

48. Lusk, J.L.; House, L.O.; Valli, C.; Jaeger, S.R.; Moore, M.; Morrow, J.L.; Traill, W.B. Effect of information about benefits of biotechnology on consumer acceptance of genetically modified food: Evidence from experimental auctions in the United States, England, and France. Eur. Rev. Agric. Econ. 2004, 31, 179-204. [CrossRef]

49. Lea, E.; Worsley, T. Australians' organic food beliefs, demographics and values. Br. Food J. 2005, 107, 855-869. [CrossRef]

50. Saarela, M.; Lähteenmäki, L.; Crittenden, R.; Salminen, S.; Mattila-Sandholm, T. Gut bacteria and health foods-the European perspective. Int. J. Food Microbiol. 2002, 78, 99-117. [CrossRef]

51. Vanhonacker, F.; van Loo, E.J.; Gellynck, X.; Verbeke, W. Flemish consumer attitudes towards more sustainable food choices. Appetite 2013, 62, 7-16. [CrossRef]

52. Rana, J.; Paul, J. Consumer behavior and purchase intention for organic food: A review and research agenda. J. Retail. Consum. Serv. 2017, 38, 157-165. [CrossRef]

53. Aertsens, J.; Mondelaers, K.; Verbeke, W.; Buysse, J.; van Huylenbroeck, G. The influence of subjective and objective knowledge on attitude, motivations and consumption of organic food. Br. Food J. 2011, 113, 1353-1378. [CrossRef]

54. Fernqvist, F.; Ekelund, L. Credence and the effect on consumer liking of food-A review. Food Qual. Prefer. 2014, 32, 340-353. [CrossRef]

55. de Magistris, T.; Gracia, A. The decision to buy organic food products in Southern Italy. Br. Food J. 2008, 110, 929-947. [CrossRef]

56. Hoek, A.C.; Luning, P.A.; Weijzen, P.; Engels, W.; Kok, F.J.; de Graaf, C. Replacement of meat by meat substitutes. A survey on person- and product-related factors in consumer acceptance. Appetite 2011, 56, 662-673. [CrossRef]

57. Roininen, K.; Tuorila, H.; Zandstra, E.H.; de Graaf, C.; Vehkalahti, K.; Stubenitsky, K.; Mela, D.J. Differences in health and taste attitudes and reported behaviour among Finnish, Dutch and British consumers: A cross-national validation of the Health and Taste Attitude Scales (HTAS). Appetite 2001, 37, 33-45. [CrossRef]

58. Özsomer, A. The Interplay between Global and Local Brands: A Closer Look at Perceived Brand Globalness and Local Iconness. J. Int. Mark. 2012, 20, 72-95. [CrossRef]

59. Brown, C. Consumers' preferences for locally produced food: A study in southeast Missouri. Am. J. Altern. Agric. 2003, 18, 213-224. [CrossRef]

60. Hefle, S.L.; Furlong, T.J.; Niemann, L.; Lemon-Mule, H.; Sicherer, S.; Taylor, S.L. Consumer attitudes and risks associated with packaged foods having advisory labeling regarding the presence of peanuts. J. Allergy Clin. Immunol. 2007, 120, 171-176. [CrossRef]

61. Bernués, A.; Olaizola, A.; Corcoran, K. Labelling information demanded by European consumers and relationships with purchasing motives, quality and safety of meat. Meat Sci. 2003, 65, 1095-1106. [CrossRef]

62. Frewer, L.J.; Kole, A.; de Kroon, S.M.A.V.; de Lauwere, C. Consumer Attitudes Towards the Development of Animal-Friendly Husbandry Systems. J. Agric. Environ. Ethics 2005, 18, 345-367. [CrossRef]

63. Burton, M.; Rigby, D.; Young, T.; James, S. Consumer attitudes to genetically modified organisms in food in the UK. Eur. Rev. Agric. Econ. 2001, 28, 479-498. [CrossRef]

64. Buckley, M.; Cowan, C.; McCarthy, M. The convenience food market in Great Britain: Convenience food lifestyle (CFL) segments. Appetite 2007, 49, 600-617. [CrossRef]

65. Olson, D.G. Irradiation of food. Food Technol. 1998, 52, 56-62.

66. Forbes, S.L.; Cohen, D.A.; Cullen, R.; Wratten, S.D.; Fountain, J. Consumer attitudes regarding environmentally sustainable wine: An exploratory study of the New Zealand marketplace. J. Clean. Prod. 2009, 17, 1195-1199. [CrossRef]

67. Lappalainen, R.; Kearney, J.; Gibney, M. A pan EU survey of consumer attitudes to food, nutrition and health: An overview. Food Qual. Prefer. 1998, 9, 467-478. [CrossRef]

68. Grunert, K.G.; Bech-Larsen, T.; Bredahl, L. Three issues in consumer quality perception and acceptance of dairy products. Int. Dairy J. 2000, 10, 575-584. [CrossRef]

69. Lähteenmäki, L.; Lampila, P.; Grunert, K.; Boztug, Y.; Ueland, Ø.; Åström, A.; Martinsdóttir, E. Impact of health-related claims on the perception of other product attributes. Food Policy 2010, 35, 230-239. [CrossRef]

70. McTavish, S.; Network Graphing with Gephi. Archives Unleashed. Available online: https://cloud.archivesunleashed.org/ derivatives/gephi (accessed on 17 December 2020).

71. Cheung, R.; Lau, M.M.; Lam, A.Y.C. Factors affecting consumer attitude towards organic food: An empirical study in Hong Kong. J. Glob. Sch. Mark. Sci. 2015, 25, 216-231. [CrossRef]

72. Teng, C.-C.; Wang, Y.-M. Decisional factors driving organic food consumption: Generation of consumer purchase intentions. Br. Food J. 2015, 117, 1066-1081. [CrossRef]

73. Tung, S.; Shih, C.; Wei, S.; Chen, Y. Attitudinal inconsistency toward organic food in relation to purchasing intention and behavior: An illustration of Taiwan consumers. Br. Food J. 2012, 114, 997-1015. [CrossRef] 
74. Voon, J.P.; Ngui, K.S.; Agrawal, A. Determinants of Willingness to Purchase Organic Food: An Exploratory Study Using Structural Equation Modeling. Int. Food Agribus. Manag. Rev. 2011, 14, 103-120.

75. Singh, A.; Verma, P. Factors influencing Indian consumers' actual buying behaviour towards organic food products. J. Clean. Prod. 2017, 167, 473-483. [CrossRef]

76. Hsu, S.-Y.; Chang, C.-C.; Lin, T.T. An analysis of purchase intentions toward organic food on health consciousness and food safety with/under structural equation modeling. Br. Food J. 2016, 118, 200-216. [CrossRef]

77. Gassler, B.; Xiao, Q.; Kühl, S.; Spiller, A. Keep on grazing: Factors driving the pasture-raised milk market in Germany. Br. Food J. 2018, 120, 452-467. [CrossRef]

78. Gineikiene, J.; Kiudyte, J.; Degutis, M. Functional, organic or conventional? Food choices of health conscious and skeptical consumers. Balt. J. Manag. 2017, 12, 139-152. [CrossRef]

79. López Galán, B.S.; Gracia Royo, A.; Barreiro Hurlé, J. Knowledge, environment or health? Investigating the factors that explain organic food consumption in Spain. Itea Inf. Téc. Económica Agrar. 2013, 109, 86-106.

80. Grubor, A.; Djokic, N.; Djokic, I.; Kovac-Znidersic, R. Application of health and taste attitude scales in Serbia. Br. Food J. 2015, 117, 840-860. [CrossRef]

81. Grubor, A.; Đokić, N. Determinants of Choice of Global and National Food Products' Brands. Strateg. Manag. 2015, 20 , 58-67.

82. Hoque, M.Z.; Alam, M.N. What Determines the Purchase Intention of Liquid Milk during a Food Security Crisis? The Role of Perceived Trust, Knowledge, and Risk. Sustainability 2018, 10, 3722. [CrossRef]

83. Ahmad, M.S.; Jamil, A.; Latif, K.F.; Ramayah, T.; Ai Leen, J.Y.; Memon, M.; Ullah, R. Using food choice motives to model Pakistani ethnic food purchase intention among tourists. Br. Food J. 2019, 122, 1731-1753. [CrossRef]

84. Aitken, R.; Watkins, L.; Williams, J.; Kean, A. The positive role of labelling on consumers' perceived behavioural control and intention to purchase organic food. J. Clean. Prod. 2020, 255, 120334. [CrossRef]

85. Dentoni, D.; Tonsor, G.T.; Calantone, R.; Christopher Peterson, H. Disentangling direct and indirect effects of credence labels. Br. Food J. 2014, 116, 931-951. [CrossRef]

86. Rankin, A.; Bunting, B.P.; Poínhos, R.; van der Lans, I.A.; Fischer, A.R.; Kuznesof, S.; Almeida, M.D.V.; Markovina, J.; Frewer, L.J.; Stewart-Knox, B.J. Food choice motives, attitude towards and intention to adopt personalised nutrition. Public Health Nutr. 2018, 21, 2606-2616. [CrossRef]

87. Kim, J.; Fang, S. Decisions to choose genetically modified foods: How do people's perceptions of science and scientists affect their choices? J. Sci. Commun. 2020, 19, A01. [CrossRef]

88. Chen, M. An integrated research framework to understand consumer attitudes and purchase intentions toward genetically modified foods. Br. Food J. 2008, 110, 559-579. [CrossRef]

89. Chang, H.H.; Huang, C.Y.; Fu, C.S.; Hsu, M.T. The effects of innovative, consumer and social characteristics on willingness to try nano-foods: Product uncertainty as a moderator. Inf. Technol. People 2017, 30, 653-690. [CrossRef]

90. Zhang, M.; Li, L.; Bai, J. Consumer acceptance of cultured meat in urban areas of three cities in China. Food Control 2020, 118, 107390. [CrossRef]

91. Coppola, A.; Verneau, F.; Caracciolo, F. Neophobia in Food Consumption: An Empirical Application of the Ftns Scale in Southern Italy. Ital. J. Food Sci. 2014, 26, 81-90.

92. Padilla Bravo, C.; Cordts, A.; Schulze, B.; Spiller, A. Assessing determinants of organic food consumption using data from the German National Nutrition Survey II. Food Qual. Prefer. 2013, 28, 60-70. [CrossRef]

93. Yazar, E.E.; Burucuoğlu, M. Consumer Attitude towards Organic Foods: A Multigroup Analysis across Genders. Istanb. Bus. Res. 2019, 48, 176-196. [CrossRef]

94. Verneau, F.; Caracciolo, F.; Coppola, A.; Lombardi, P. Consumer fears and familiarity of processed food. The value of information provided by the FTNS. Appetite 2014, 73, 140-146. [CrossRef]

95. Boobalan, K.; Nachimuthu, G.S.; Sivakumaran, B. Understanding the psychological benefits in organic consumerism: An empirical exploration. Food Qual. Prefer. 2021, 87, 104070. [CrossRef]

96. Dowd, K.; Burke, K.J. The influence of ethical values and food choice motivations on intentions to purchase sustainably sourced foods. Appetite 2013, 69, 137-144. [CrossRef]

97. Jorge, E.; Lopez-Valeiras, E.; Gonzalez-Sanchez, M.B. The role of attitudes and tolerance of ambiguity in explaining consumers willingness to pay for organic wine. J. Clean. Prod. 2020, 257, 120601. [CrossRef]

98. Hansmann, R.; Baur, I.; Binder, C.R. Increasing organic food consumption: An integrating model of drivers and barriers. J. Clean. Prod. 2020, 275, 123058. [CrossRef]

99. Li, S.; Jaharuddin, N.S. Identifying the key purchase factors for organic food among Chinese consumers. Front. Bus. Res. China 2020, 14, 25. [CrossRef]

100. Nystrand, B.T.; Olsen, S.O. Consumers' attitudes and intentions toward consuming functional foods in Norway. Food Qual. Prefer. 2020, 80, 103827. [CrossRef]

101. Yarimoglu, E.; Kazancoglu, I.; Bulut, Z.A. Factors influencing Turkish parents' intentions towards anti-consumption of junk food. Br. Food J. 2019, 121, 35-53. [CrossRef]

102. Chang, H.-P.; Ma, C.-C.; Chen, H.-S. Climate Change and Consumer's Attitude toward Insect Food. Int. J. Environ. Res. Public. Health 2019, 16, 1606. [CrossRef] 
103. Khalid, N.R.; Che Wel, C.A.; Mokhtaruddin, S.A. Product Positioning as a Moderator for Halal Cosmetic Purchase Intention. Iran. J. Manag. Stud. 2021, 14, 39-60. [CrossRef]

104. Liang, A.R.-D.; Lim, W.-M. Why do consumers buy organic food? Results from an S-O-R model. Asia Pac. J. Mark. Logist. 2021, 33, 394-415. [CrossRef]

105. Vega-Zamora, M.; Torres-Ruiz, F.J.; Parras-Rosa, M. Key Determinants of Organic Food Consumption: The Case of Olive Oil in Spain. HortScience 2018, 53, 1172-1178. [CrossRef]

106. Nijssen, E.J.; Reinders, M.J.; Banovic, M. Referent product information from a credible source: How front line employees can stimulate acceptance of incrementally new food products. Food Qual. Prefer. 2021, 87, 104038. [CrossRef] 